\section{PREVALENCE OF ECTOPIC THYMIC TISSUE IN MYASTHENIA GRAVIS AND ITS CLINICAL SIGNIFICANCE}

Forty patients with myasthenia gravis underwent maximal thymectomy. Complete histologic study findings were available for 38 patients. The prevalence of ectopic thymic tissue was $39.5 \%$ (15 of 38). On the basis of the presence or absence of ectopic thymic tissue, patients were divided into two groups: group I had ectopic thymic tissue and group II had no ectopic thymic tissue. Male/female ratio was almost equal (1.1:1) in group I, whereas in group II the ratio was 1:2.8. The duration of the disease was less than 1 year in $80 \%$ of group I and $47.8 \%$ of group II patients $(p=0.05)$. Furthermore, ectopic thymic tissue (group I) was associated with poor outcome of operation ( $p=0.003$ ). Only $2(13.3 \%)$ of 15 patients in group I had complete remission as compared with $11(47.8 \%)$ of 23 patients in group II. Thus it appears that the presence of ectopic thymic tissue not only modifies some of the clinical parameters of myasthenia gravis, but also could serve as a prognostic factor in predicting the outcome of operation. (J THORAC CARDIOVASC SURG 1995;109:632-5)

M. Ashour, FRCS, Riyadh, Saudi Arabia
T here are ample data now to suggest that the thymus gland plays a major role in the pathogenesis of myasthenia gravis (MG). ${ }^{1-3}$ Thymectomy is increasingly being accepted as a treatment modality for $\mathrm{MG} .^{4-8}$ However, thymectomy does not achieve complete remission rates consistently in all patients. In some of these cases, foci of thymic tissue have been left behind at various locations. ${ }^{8,9}$ Some of these ectopic locations are accessible through various approaches used for thymectomy. On the other hand, ectopic thymic tissue in the retrocarinal area is not accessible through even the most aggressive approach. ${ }^{10}$ The significance of ectopic thymic tissue with regard to clinical characteristics of $M G$ and outcome of operation, to my knowledge, has not been studied before. In this report I present the pattern of MG in patients with ectopic tissue and compare it with the pattern in those without ectopic thymic tissue.

\section{Patients and methods}

The cases of 40 patients with MG who were operated on consecutively between July 1987 and June 1993 at King Khalid University Hospital, Riyadh, Saudi Arabia, were

From King Khalid University Hospital, Riyadh, Saudi Arabia.

Received for publication April 29, 1994.

Accepted for publication Sept. 29, 1994.

Address for reprints: Mahmoud H. Ashour, FRCS, Associate Professor, Thoracic Surgery, King Khalid University Hospital, P.O. Box 7805, Riyadh 11472, Saudi Arabia.

Copyright (C) 1995 by Mosby-Year Book, Inc.

$0022-5223 / 95 \$ 3.00+0 \quad \mathbf{1 2 / 1 / 6 0 9 6 4}$ reviewed retrospectively. MG was diagnosed in the patients on the basis of clinical presentation and edrophonium chloride (Tensilon) test results. All were receiving anticholinesterase inhibitors. Fifteen patients were receiving steroids and three were also receiving azathioprine. Most were having uncontrolled myasthenic symptoms with medical treatment. Any attempt to taper off medications resulted in increased disability.

Before operation all patients had a mean of three sessions of plasmapheresis. This protocol was adopted with the aim of not only improving patient status before operation, but also decreasing the incidence of morbidity after operation. Patients underwent transcervical-transsternal "maximal" thymectomy according to technique described by Jaretzki and Wolff. ${ }^{11}$ During the first phase of operation via transcervical incision, upper poles of thymus were isolated carefully. A thorough search was made to locate any suspicious thymic rests in the retrothyroid area and in the pretracheal adipose tissue. Most of the adipose tissue in these areas was carefully removed and sent for histologic examination in separate containers. The second phase of operation was done via the transsternal approach. All visible thymus gland was excised en bloc with anterior mediastinal adipose tissue. The left phrenic nerve was lifted off the pericardium to facilitate gland dissection in the hilar region. Adipose tissues in the retro-innominate-vein area, aortocaval window, aortopulmonary window, and both cardiophrenic angles were sent separately for histopathologic examination.

Multiple microscopic sections were taken from each specimen and stained with hematoxylin and eosin. These were examined for thymic tissues. Thymic tissue was identified by the presence of Hassall's corpuscles. If the identification of thymic tissues was in doubt, staining with T-cell markers and immunohistochemical staining with cytokeratin were done for the identification of thymocytes and epithial cells, respectively. On the first day after operation all patients were started on half the amount of 
Table I. Age and sex distribution

\begin{tabular}{|c|c|c|c|c|}
\hline Age group (yr) & $\begin{array}{c}\text { Male } \\
\text { patients }\end{array}$ & $\begin{array}{l}\text { Female } \\
\text { patients }\end{array}$ & Total & Percent \\
\hline $\mathrm{Up}_{\mathrm{p}}$ to 20 & 3 & 11 & 14 & 36.8 \\
\hline $21-40$ & 8 & 12 & 20 & 52.6 \\
\hline $40+$ & 3 & 1 & 4 & 10.5 \\
\hline
\end{tabular}

Table II. Details of ectopic thymic tissue

\begin{tabular}{|c|c|c|}
\hline $\begin{array}{l}\text { Patient } \\
\text { no. }\end{array}$ & $\begin{array}{c}\text { No. of } \\
\text { ectopic sites }\end{array}$ & Site of ectopic thymic tissue \\
\hline 1 & 1 & Right cardiophrenic angle \\
\hline 2 & 2 & $\begin{array}{l}\text { Left retrothyroid lobe and left cardiophrenic } \\
\text { angle }\end{array}$ \\
\hline 3 & 1 & Retro-innominate vein \\
\hline 4 & 1 & Below thyroid isthmus \\
\hline 5 & 1 & Pretracheal tissue \\
\hline 6 & 1 & Left retrothyroid lobe \\
\hline 7 & 1 & Left carotid sheath \\
\hline 8 & 1 & Aortopulmonary window \\
\hline 9 & 4 & $\begin{array}{l}\text { Right and left cardiophrenic angles, adja- } \\
\text { cent to left thyroid lobe, and retro-in- } \\
\text { nominate vein. }\end{array}$ \\
\hline 10 & 1 & Left retrothyroid lobe \\
\hline 11 & 1 & Adjacent to left thyroid lobe \\
\hline 12 & 1 & Left retrothyroid lobe \\
\hline 13 & 1 & Adjacent to left thyroid lobe \\
\hline 14 & 1 & Below thyroid isthmus \\
\hline 15 & 1 & Below thyroid isthmus \\
\hline
\end{tabular}

their preoperative medications. The outcome of operation was judged according to the following criteria: (1) complete remission was achieved when the patient had no symptoms and received no drugs, (2) pharmacologic remission occurred when the patient had no symptoms with half or less of the amount of preoperative drugs, (3) improved condition occurred in patients who had no symptoms with the same preoperative drugs, and (4) no change occurred when the patient had symptoms with medical therapy.

Statistical analysis was done by Mann-Whitney ranksum test with use of BMDP statistical package version 7.01, 1994 (University of California Press, Berkeley, Calif.).

\section{Results}

Complete histologic study findings were available for 38 of 40 patients. The two patients with incomplete data shall not be considered further. There were 14 male and 24 female patients with ages ranging from 10 to 61 years and a mean age of 26.8 years (Table I). Duration of disease ranged from 1 month to 20 years with mean of 34.9 months. Fifteen patients $(39.5 \%)$ had ectopic thymic tissue at 19 locations (Table II). Ectopic locations were in the neck in $63.2 \%$ of cases (12 of 19) and in the cardiophrenic angles in 21\% (4 of 19). Eight (57\%)
Table III. Ectopic and nonectopic group characteristics

\begin{tabular}{|c|c|c|}
\hline \multirow[b]{2}{*}{ Characteristics } & \multicolumn{2}{|c|}{ No. of patients } \\
\hline & Group I & Group II \\
\hline \multicolumn{3}{|l|}{ Sex } \\
\hline Male & 8 & 6 \\
\hline Female & 7 & 17 \\
\hline \multicolumn{3}{|l|}{ Age } \\
\hline Up to $20 \mathrm{yr}$ & 5 & 9 \\
\hline $21-40 \mathrm{yr}$ & 9 & 11 \\
\hline $40+y r$ & 1 & 3 \\
\hline \multicolumn{3}{|l|}{ Duration of symptoms } \\
\hline Up to $1 \mathrm{yr}$ & 12 & 11 \\
\hline$>1 \mathrm{yr}$ & 3 & 12 \\
\hline \multicolumn{3}{|l|}{ Osserman class } \\
\hline I & 3 & 3 \\
\hline II & 7 & 8 \\
\hline III & 5 & 9 \\
\hline IV & 0 & 3 \\
\hline \multicolumn{3}{|l|}{$\begin{array}{l}\text { Anti-acetylcholine receptor } \\
\text { antibodies }\end{array}$} \\
\hline Positive & 5 & 10 \\
\hline Negative & 3 & 10 \\
\hline Not done & 7 & 3 \\
\hline \multicolumn{3}{|l|}{ Histologic type of thymus } \\
\hline Hyperplasia & 14 & 19 \\
\hline Atrophic & 1 & 4 \\
\hline \multicolumn{3}{|l|}{ Outcome of thymectomy } \\
\hline Complete remission & $2(13.3 \%)$ & $11(47.8 \%)$ \\
\hline Pharmacologic remission & $8(53.3 \%)$ & $12(52.2 \%)$ \\
\hline Improved & $5(33.35 \%)$ & $0(0 \%)$ \\
\hline
\end{tabular}

of 14 male patients and $7(29.2 \%)$ of 24 female patients had ectopic thymic tissue. Fourteen $(41.2 \%)$ of 34 patients with ectopic thymic tissue were younger than 40 years old as compared with only 1 of 5 patients older than 40 years. Fourteen $(42.4 \%)$ of 33 patients with thymic hyperplasia had ectopic thymic tissue whereas only 1 of 5 with atrophic thymus had ectopic thymic tissue.

On the basis of the presence or absence of ectopic thymic tissue, 38 patients were divided into two groups: group I patients had ectopic thymic tissue and group II patients had no ectopic thymic tissue. The various characteristics of the two groups are depicted in Table III. Male:female ratio was almost equal (1.1:1) in group I whereas in group II the ratio was 1:2.8. Of group I patients $80 \%$ (12 of 15$)$ had duration of disease up to 1 year whereas in group II only $47.8 \%$ (11 of 23 ) had duration of disease up to 1 year $(p=0.05)$. There was no significant difference in Osserman class in the two groups.

The follow-up period ranged from 4 months to 6 years with a mean of 14.5 months. All patients in 
both groups benefited from thymectomy. However, the complete remission rate in group I was only $13.3 \%$ ( 2 of 15 ) compared with $47.8 \%$ (11 of 23 ) in group II. All the remaining patients in group II achieved pharmacologic remission whereas in group I only $53.3 \%$ ( 8 of 15 ) achieved pharmacologic remission and $33.3 \%$ (5 of 15 ) had improved conditions $(p=0.003)$.

\section{Discussion}

Thymus gland develops as two separate lobes from the third pharyngeal pouch along with inferior parathyroid glands. During subsequent growth it descends into the anterior mediastinum to a variable extent and two lobes join at a variable distance for variable length. This complicated development provides ample scope for ectopic and abnormal position of thymus gland as was seen in two patients in this series in whom one lobe or the whole of the thymus was seen passing behind the left innominate vein. Jaretzki and Wolf ${ }^{11}$ noted $98 \%$ of patients with MG had anatomic variability in the distribution of thymic tissue in the mediastinum. Goldstein and Mackay ${ }^{12}$ reported $20 \%$ of normal subjects had ectopic thymic tissue.

In an autopsy study on subjects without myasthenia gravis, $44.4 \%$ had ectopic thymic tissue in anterior mediastinal fat and $7.4 \%$ had ectopic thymic tissue in the retrocarinal area. ${ }^{10}$ In patients with myasthenia gravis, $72.2 \%$ had ectopic thymic tissue in anterior mediastinal fat. ${ }^{13}$ In the present series, I found ectopic thymic tissue in $39.5 \%$ of patients at variable locations (Table II). Twelve $(63.2 \%)$ of 19 ectopic sites were in the neck close to the thyroid gland. This is understandable because embryologically the development of thyroid and thymus glands is closely related. On several occasions, I have found one or both inferior parathyroid glands embedded in the substance of thymus gland near the upper poles. Four $(21 \%)$ of 19 ectopic sites were in cardiophrenic angles.

Although most patients had a single ectopic site, two patients had ectopic thymic tissue at multiple locations. One of these two had ectopic thymic tissue at four different locations. This raises the question of multiple ectopic sites in at least some patients at hitherto unknown sites. Ectopic thymic tissue was found in $57 \%$ of male patients and $29.2 \%$ of female patients. This indicates a relative preponderance of ectopic tissue in the male population. Ectopic thymic tissue was seen more frequently in patients younger than 40 years old compared with those older than 40 years $(41.2 \%$ versus $25 \%$ ). On the basis of the high prevalence of ectopic thymic tissue in the neck and cardiophrenic angles, I recommend that dissection in these areas should form an integral part of operation for MG, particularly in male patients younger than age 40 years.

The clinical characteristics of group I and group II patients are shown (Table II). Some of these were surprisingly different between groups. Male:female ratio was almost equal in group I whereas women outnumbered men by a factor of 2.8 in group II. The duration of disease was less than 1 year in $80 \%$ of group I patients and $47.8 \%$ of group II patients $(p=$ 0.05 ). In group I, the presence of ectopic thymic tissue not only modified some of the clinical pattern of MG, but also altered the outcome of operation. The complete remission rate was $13.3 \%$ in group I and $47.8 \%$ in group II. Furthermore, all the remaining patients in group II had pharmacologic remission whereas in group I, 53.3\% (8 of 15) had pharmacologic remission and 33.3\% (5 of 15) had improved conditions $(p=0.003)$. When the complete remission rate is taken as the only parameter to judge the outcome of operation, it is apparent that patients with ectopic thymic tissue had less favorable outcomes as compared with the outcomes of those without ectopic thymic tissue. The presence of ectopic thymic tissue, thus, could have prognostic value in determining the outcome of operation. Poor outcome of operation in these patients might be a result of still more ectopic sites that are inaccessible by the present radical techniques of thymectomy.

In conclusion, it seems that the presence of ectopic thymic tissue altered some of the clinical parameters of MG and was also associated with poor outcome of operation.

I thank Ms. Timmie M. Luces for typing this manuscript.

\section{REFERENCES}

1. Lennon VA, Lambert EH. Myasthenia gravis induced by monoclonal antibodies to acetylcholine receptors. Nature 1980;285:238-40.

2. Wekerle $\mathrm{H}$, Muller-Hermelink HK. The thymus in myasthenia gravis. Curr Top Pathol 1986;75:179-206.

3. Lennon VA. The immunopathology of myasthenia gravis. Hum Pathol 1978;9:541-51.

4. Keyness GL. The results of thymectomy in myasthenia gravis. BMJ 1949;2:611-6.

5. Eaton LM, Clargett OT. Present status of thymec- 
tomy in the treatment of myasthenia gravis. Am J Med 1955;19:703-15.

6. Papatestas AE, Genkins G, Morowitz SH, Kornfeld P. Thymectomy in myasthenia gravis: pathologic, clinical and electrophysiological correlation. Ann N Y Acad Sci 1976;274:555-73.

7. Fischer JE, Grinvalski HT, Nussbaum MS, Sayers HJ, Cole RE, Samaha FJ. Aggressive surgical approach for drug-free remission from myasthenia gravis. Ann Surg 1987;45:496-503.

8. Jaretzki A III, Penn AS, Younger DS, et al. "Maximal" thymectomy for myasthenia gravis: results. J Thorac Cardiovasc SuRg 1988;95:747-57.

9. Rosenberg M, Jauregui WD, Herrera MR, Roncoroni AJ, Rojas OR, Olmedo GSM. Recurrence of thymic hyperplasia after transsternal thymectomy in myasthenia gravis. Chest 1986;89:888-9.

10. Fukai I, Funato $\mathrm{Y}$, Mizumo $\mathrm{T}$, Hashimoto $\mathrm{T}$, Masaoka A. Distribution of thymic tissue in the mediastinal adipose tissue. J Thorac Cardiovasc SuRG 1991;101:1099-102.

11. Jaretzki A III, Wolff M. "Maximal" thymectomy for MG: surgical anatomy and operative technique. J Thorac Cardiovasc Surg 1988;96:711-6.

12. Goldstein G, Mackay I. The human thymus. London: Heinemann Medical Books, 1969:165-254.

13. Masaoka A, Nagaoka Y, Kotabe Y. Distribution of thymic tissue at the anterior mediastinum: current procedure in thymectomy. $\mathrm{J}$ THORAC CARDIOVASC SURG 1975;70:747-54.

\section{1-800-55-MOSBY}

This number links you to the full text of articles published in over 25,000 journals, including all Mosby journals. MOSBY Document Express $^{\mathrm{TM}}$, a rapid response information retrieval service, provides quick turnaround, 24-hour availability, and speedy delivery methods. For inquiries and pricing information, call our toll-free, 24-hour order line: 1-800-55-MOSBY; outside the United States: 415-259-5046; fax: 415-259-5019; E-mail: mosbyexp@class.org. 